\title{
OPINI MAHASISWA DALAM PEMILU PRESIDEN 2019 (STUDI KASUS AKTIFIS BEM FISIP TENTANG \#2019GANTIPRESIDEN PADA LIMA (5) PERGURUAN TINGGI DI KABUPATEN JEMBER)
}

\author{
Juariyah, Nurul Wijayanti \\ Program Studi Ilmu Komunikasi, Fakultas Ilmu Sosial dan Ilmu Politik \\ Universitas Muhammadiyah Jember \\ juariyah@unmuhjember.ac.id \\ nurulwijayanti948@gmail.com
}

\begin{abstract}
Opinion is formed through information in the mass media that causes controversy and reap the response of the community to finally be able to influence the decision in the general election. The 2019 election was a very interesting political event, because at the same time the Indonesian people elected the President and the people's representatives. The theory used in this research is the theory of opinion formation that has been developed by Noelle-Neumann, the Spiral of Silence theory. The research method uses a qualitative approach with in-depth interview techniques at ten (10) Bem activists in 5 (five) universities in Jember Regency. The results showed that the opinions that emerged from several Bem FISIP administrators in Jember District were very diverse, they channeled them through social media which was considered as the most updated media.
\end{abstract}

Keywords: Student Opinion, Presidential Election

\begin{abstract}
Abstrak
Opini terbentuk melalui informasi yang ada di media massa sehingga menimbulkan kontroversi dan menuai tanggapan dari masyarakat hingga akhirnya mampu mempengaruhi keputusan dalam pemilihan umum. Pemilu 2019 merupakan perhelatan politik yang sangat menarik, karena pada saat yang sama masyarakat Indonesia memilih Presiden dan wakil rakyat. Teori yang digunakan dalam penelitian ini adalah teori pembentukan opini yang telah dikembangkan oleh Noelle-Neumann yaitu teori Spiral of Silence. Metode penelitiannya menggunakan pendekatan kualitatif dengan teknik wawancara mendalam pada sepuluh (10) aktifis Bem di 5 (lima) perguruan tinggi di Kabupaten Jember. Hasil penelitian menunjukkan bahwa opini yang mucul dari beberapa pengurus Bem Fisip di Kabupaten Jember sangat beragam mereka menyalurkannya melalui media sosial yang dianggap sebagai media yang paling terupdate.
\end{abstract}

Kata Kunci : Opini Mahasiswa, Pemilu Presiden 


\section{Pendahuluan}

Saat ini komunikasi politik di Indonesia semakin menarik. Media massa, khususnya televisi dan surat kabar juga internet akan menjadi media utama dalam meningkatkan citra diri seorang politisi khusunya menjelang pemilihan umum seperti saat ini. Kelak akan semakin banyak politisi, baik sebagai calon presiden ataupun calon wakil presiden yang akan memiliki blog dan situs mereka masing-masing untuk meraih dukungan khalayak guna menduduki jabatan yang mereka inginkan, terlepas dari apakah pengelolanya adalah diri mereka sendiri atau gate keeper yang khusus digunakan untuk itu (Mulyana, 2014:22). Sebagai akibat dari terjadinya banjir informasi (the flood of information), pengetahuan masyarakat semakin bertambah disertai daya nalar yang semakin meningkat, yang pada gilirannya semakin kritis terhadap kebijakan pemerintah (Effendy, 2004:163). Informasi media kemudian membentuk persepsi, pendapat, sikap, dan akhirnya tindakan publik.

Salah satu pemberitaan politik yang cukup menarik perhatian adalah mengenai munculnya \#2019GantiPresiden. Ramainya pemberitaan mengenai \#2019GantiPresiden di media massa menimbulkan berbagai reaksi dari publik. Awal mula munculnya tagar tersebut diperkenalkan oleh politikus dari Partai $\underline{\text { Keadilan Sejahtera yaitu Mardani Ali }}$ Sera dengan tujuan untuk memberikan pendidikan politik kepada masyarakat, pernyatan Mardani diperkuat dengan pernyataan Presiden Partai Keadilan Sejahtera Sohibul Iman. Mardani menyebutkan bahwa tagar ini meniru kesuksesan pemain Liverpool Mohamed $\underline{\text { Salah. }}$ Mardani juga menyebut tagar ini merupakan antitesis dari kampanye pendukung Joko Widodo di media sosial. Tagar tersebut banyak menuai pro dan kontra dari publik. Karena dari banyaknya lapisan masyarakat tentunya memiliki pendapat tersendiri mengenai munculnya \#2019GantiPresiden. Fenomena tersebut menjadi viral di media massa dan memperoleh berbagai tanggapan yang beraneka ragam dari masyarakat terutama pengguna media massa.. \#2019 GantiPresiden banyak bermunculan di media massa, karena saat ini media massa merupakan media yang paling umum digunakan oleh masyarakat luas. Saat ini hampir seluruh masyarakat aktif dalam menggunakan media massa, karena melalui media massa sebuah informasi dapat diperoleh secara lebih cepat. 
Informasi yang dibahas dalam penelitian ini adalah mengenai \#2019GantiPresiden. Meskipun sama sama membahas mengenai opini publik namun informan yang dituju dalam penelitian ini adalah dari kalangan mahasiswa yang sudah memiliki hak untuk memberikan suaranya dalam pemilu. Dari tersebarnya suatu informasi melalui sebuah media tentu akan menuai banyak pro kontra dari mahasiswa hingga nantinya dapat mempengaruhi keputusan dalam pemilihan umum. Seperti yang kita ketahui informasi mengenai \#2019GantiPresiden tersebar dengan sangar cepat di media massa. Selain media yang digunakan dalam upaya menyebarluaskan informasi, penelitian ini juga memiliki kesamaan mengenai opini publik. Bagaimana suatu opini terbentuk melalui informasi yang ada di media massa sehingga menimbulkan kontroversi dan menuai tanggapan dari masyarakat hingga akhirnya mampu mempengaruhi keputusan dalam pemilihan umum.

Dengan munculnya \#2019Ganti Presiden di media massa dapat menimbulkan opini - opini yang beraneka ragam dari berbagai kalangan masyarakat terutama di kalangan mahasiswa. Dari opini - opini tersebut dapat diketahui bahwa nantinya akan ada yang menyatakan pro dan kontra dengan tagar tersebut. Dengan munculnya opini mengenai \#2019GantiPresiden tentunya akan dapat mempengaruhi keputusan yang diambil dalam pemilihan presiden pada pemilu 2019 dikarenakan tagar tersebut tentunya memiliki kekuatan dalam memperngaruhi pilihan politik seseorang.

\section{Tinjauan Pustaka}

\section{Spiral of Silence}

Teori yang menarik dalam lingkup pembentukan opini telah dikembangkan oleh Noelle-Neumann (1974), teori ini bertitik tolak dari asumsi dasar bahwa orang - orang umumnya secara alamiah memiliki rasa takut terkucil. Dan dalam pengungkapan opini mereka berusaha menyatu dengan mengikuti opini mayoritas (dalam McQuail, 1987:252). Spiral of Silence adalah sebuah teori yang lebih memberikan perhatian pada pandangan mayoritas dan menekan pandangan minoritas. Mereka yang berada di pihak minoritas akan cenderung kurang tegas dalam mengemukakan pandangannya, dan hal ini akan mendorong terjadinya spiral komunikasi yang menuju kebawah. Sebaliknya, mereka yang berada di pihak mayoritas akan merasa percaya diri dengan pengaruh dari pandangan mereka dan 
terdorong untuk menyampaikannya kepada orang lain. (Morissan, 2013:526)

Istilah umum 'spiral kebisuan' (spiral of silence) diberikan oleh Noelle-Neumann bagi gejala ini karena logika yang mendasarinya berujar bahwa semakin tersebar versi konsensus opini yang dominan oleh media massa dalam masyarakat, semakin senyap pula suara perorangan yang bertentangan, yang karenanya meningkatkan dampak media dan juga proses 'spiral' (McQuail, 1987: 252). Noelle-Neumann menyebut situasi tersebut sebagai spiral keheningan yang terjadi ketika orang mengemukakan opininya karena merasa pandangannya mewakili pandangan yang populer, sedangkan mereka yang merasa opininya tidak mewakili pandangan populer memilih untuk diam. Proses ini terjadi dalam pola atau bentuk menyerupai spiral sedemikian rupa sehingga satu pendapat akan berakhir dengan publisitas dan popularitas tinggi, sedangkan pendapat lainnya akan berakhir dengan publisitas dan popularitas rendah. (Morissan, 2013:527) Secara ringkas teori ini ingin menjawab pertanyaan, mengapa orang orang dari kelompok minoritas sering merasa perlu untuk menyembunyikan pendapat dan pandangannya ketika berada dalam kelompok mayoritas. Seseorang merasa perlu menyembunyikan "sesuatu"nya atau pendapatnya ketika berada dalam kelompok mayoritas. (Nurudin, 2007:182)

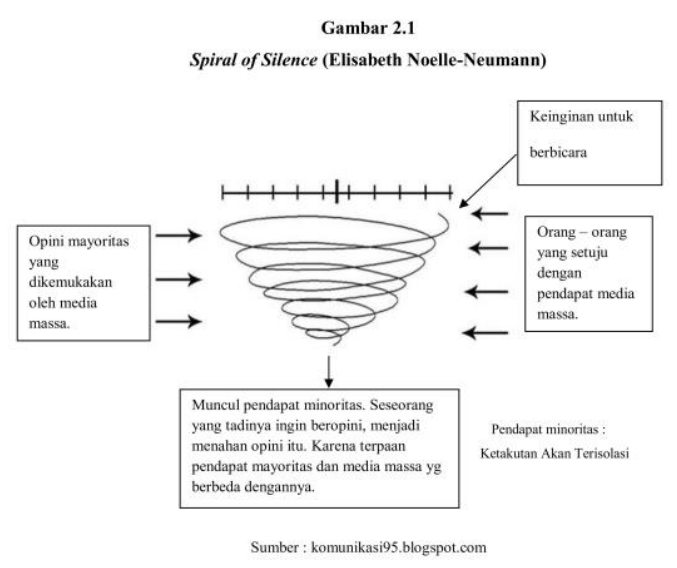

Dari gambar diatas, dapat dilihat bahwa semakin sering media massa mengemukakan pendapat yang dominan di kalangan masyarakat, makan akan semakin memudar pendapat masyarakat yang menentang pendapat dominan tersebut. Jumlah orang yang secara terbuka menentang pendapat dominan yang dikemukakan media massa akan semakin mengecil atau semakin sedikit. Asumsi ini didasarkan pada pertimbangan bahwa pada dasarnya, kebanyakan orang dalam masyarakat cenderung tidak mau mengisolasikan dirinya dari lingkungan di sekitarnya. Oleh karena itu, biarpun seseorang mempunyai sikap atau pendapat yang berbeda ia akan berusaha untuk tidak menentang secara terbuka terhadap sikap dan pendapat orang orang di lingkungan sekitarnya. 
Berbagai pendapat yang bertolak belakang itu akan berkembang dan "bertarung" baik dalam wacana keseharian maupun disebarkan melalui media massa. Baik yang pro maupun yang kontra sama - sama kuat dalam membentuk opini publik. Bahkan orang orang yang sedang berada dalam kelompok minoritas sering merasa perlu untuk mengubah pendiriannya sesuai dengan kelompok mayoritas tempat dia berada. Sebab, kalau tidak mengubah pendiriannya, ia akan merasa sendiri. Mengapa individu - individu dari kelompok minoritas dan sedang berada dalam kelompok mayoritas merasa perlu untuk diam. Salah satu alasan adalah dia tidak mau diisolasi dari pergaulan sosial di tempat dia berada. (Nurudin, 2007:183) Teori spiral kebisuan memberikan argumentasi bahwa orang selalu bertindak sebagai penilai iklim opini publik. Orang mengetahui pendapat atau pandangan mana yang populer yang lebih banyak diterima dan pandangan mana yang tidak banyak diterima orang. Dengan kata lain, orang tidak akan merasa segan untuk melakukan perkiraan berdasarkan perasaannya mengenai adanya opini publik terhadap suatu pendapat tertentu serta membuat perkiraan mengenai besarkecilnya jumlah orang-orang yang mendukung atau menolak suatu pendapat. Selain itu, orang juga memiliki kemampuan untuk memberikan penilaian terhadap arah pembicaraan seseorang apakah mendukung atau menolak suatu pendapat. Singkatnya, orang memiliki kemampuan untuk memperkirakan kekuatan argumentasi pihak lawan. (Morissan, 2013:529)

Teori ini juga memiliki kekurangan. Jika seseorang mempunyai pendirian yang sangat kuat, orang tersebut tidak akan mudah mengikuti opini mayoritas yang ada di sekitarnya misalnya jika opini itu menyangkut tentang kepercayaan. Orang ini akan mempunyai kecenderungan menolak dengan memperlihatkan perbedaan pendapatnya. Tidak terkecuali jika anda adalah seorang pemimpin opini. Seorang pemimpin opini karena memiliki pengikut yang loyal dan banyak, sulit untuk mengubah pendapatnya secara mendadak. Alasannya bisa jadi klasik, jika ia menerima ide baru sama saja menurunkan kewibawaannya di mata pengikutnya. Artinya, ada kecenderungan untuk menolak opini di tempat mayoritas sekalipun. (Nurudin, 2007:184)

\section{Metode Penelitian}

Metode penelitian yang digunakan dalam penelitian ini adalah metode kualitatif. Metode ini mampu memberikan 
pemahaman yang lebih mendalam terhadap suatu permasalahan. Dalam hal ini permasalahan yang diteliti adalah mengenai opini mahasiswa FISIP di Kabupaten Jember mengenai \#2019GantiPresiden dan apakah tagar tersebut memiliki kekuatan dalam mempengaruhi pilihan politik mahasiswa. Lokasi penelitian di Kabupaten Jember dengan sampel 10 orang perwakilan bem 5 perguruan tinggi yaitu Universitas Muhammadiyah Jember, Universitas Jember, Universitas Islam Jember, Universitas Terbuka Jember dan Universitas Moch. Sroedji Jember. Waktu penelitian dilakukan pada tanggal 1 Februari - 18 Maret 2019. Berikut daftar nama mahasiswa yang di jadikan informan dalam penelitian ini :

Tabel 3.1

Daftar Nama Informan

\begin{tabular}{|c|l|l|}
\hline No & \multicolumn{1}{|c|}{ Nama } & \multicolumn{1}{|c|}{ Keterangan } \\
\hline \multirow{2}{*}{1} & Ach. Fahmi & BEM FISIP \\
& Dzulfikri & $\begin{array}{l}\text { Universitas } \\
\text { Muhammadiyah } \\
\text { Jember }\end{array}$ \\
\hline 2 & $\begin{array}{l}\text { Rifaldo } \\
\text { Apriliyansyah }\end{array}$ & $\begin{array}{l}\text { BEM FISIP } \\
\text { Universitas } \\
\text { Muhammadiyah } \\
\text { Jember }\end{array}$ \\
\hline 3 & Nur Kholis & $\begin{array}{l}\text { BEM FISIP } \\
\text { Universitas }\end{array}$ \\
\hline
\end{tabular}

\begin{tabular}{|c|c|c|}
\hline & & Jember \\
\hline 4 & Lailatul Anisa & $\begin{array}{l}\text { BEM FISIP } \\
\text { Universitas } \\
\text { Jember }\end{array}$ \\
\hline 5 & $\begin{array}{l}\text { M. Hasyim } \\
\text { Lutfi A. }\end{array}$ & $\begin{array}{l}\text { BEM FISIP } \\
\text { Universitas Islam } \\
\text { Jember }\end{array}$ \\
\hline 6 & $\begin{array}{l}\text { Ilham } \\
\text { Wahyudi }\end{array}$ & $\begin{array}{l}\text { BEM FISIP } \\
\text { Universitas Islam } \\
\text { Jember }\end{array}$ \\
\hline 7 & $\begin{array}{l}\text { Shinta } \\
\text { Yuliana }\end{array}$ & $\begin{array}{l}\text { BEM FISIP } \\
\text { Universitas } \\
\text { Terbuka }\end{array}$ \\
\hline 8 & $\begin{array}{l}\text { Irma } \\
\text { Wulandari }\end{array}$ & $\begin{array}{l}\text { BEM FISIP } \\
\text { Universitas } \\
\text { Terbuka }\end{array}$ \\
\hline 9 & $\begin{array}{l}\text { Henry Raiden } \\
\text { Tarigan }\end{array}$ & $\begin{array}{l}\text { BEM Universitas } \\
\text { Moch. Sroedji }\end{array}$ \\
\hline 10 & Faisol Anwar & $\begin{array}{l}\text { BEM Universitas } \\
\text { Moch. Sroedji }\end{array}$ \\
\hline
\end{tabular}

Teknik analisis data model interaktif menurut Miles\&Huberman terdiri atas empat tahapan yakni pengumpulan data, reduksi data, penyajian (display) data dan penarikan kesimpulan. Tahap pertama dalam penelitian adalah proses pengumpulan data. Pada tahap ini peneliti melakukan proses pengumpulan data dengan menggunakan teknik yang telah ditentukan sejak awal. Pada penelitian kualitatif proses pengumpulan data 
dilakukan sebelum penelitian, pada saat penelitian, dan bahkan di akhir penelitian. Proses pengumpulan data pada penelitian kualitatif tidak memiliki segmen atau waktu tersendiri, melainkan sepanjang penlitian yang dilakukan proses pengumpulan data dapat dilakukan ( Herdiansyah, 2010:164).

\section{Hasil dan Pembahasan}

Tanggapan Terhadap Adanya Pro dan Kontra Mengenai \#2019GantiPresiden

Setiap isu memang selalu menimbulkan pro dan kontra tak terkecuali di bidang politik. Isu politik memang merupakan hal yang sangat sensitif untuk dibahasa karena isu politik ini melibatkan kepentingan dari beberapa pihak. Adanya pro dan kontra terhadap sebuah isu merupakan suatu hal yang biasa terjadi karena memang adanya perbedaan pendapat dari masing-orang pribadi.

"Pro dan kontra pasti ada, tentu ada yang punya keinginan untuk ganti ada juga yang tidak. Tapi itu terserah mereka mau bilang seperti apa, kembali lagi hasil akhirnya nanti tetap tergantung pada pilihan rakyat."'(Shinta Y. BEM FISIP UT)

\begin{abstract}
"Adanya pro dan kotra itu ya hal yang biasa, tapi sama saja yang penting siapapun nanti pemimpin yang terpilih harus sesuai dengan janji-janjinya."(Faisol A. BEM UMS)
\end{abstract}

Pendapat atau opini dari setiap individu sudah pasti berbeda karena setiap individu tentunya memiliki penilaian dan pemikiran tersendiri dalam menanggapi sebuah isu yang sedang berkembang. Adanya sebuah isu tentunya ada pro dan kontra di dalamnya, karena dalam setiap pernyataan tentu ada kubu yang menjadi pendukung dan sebaliknya ada kubu yang menentang.

"Dalam konteks demokrasi pro dan kontra itu hal yang biasa. Tentu ada kubu yang mendukung dengan usaha itu dan ada kubu yang menolak. Kubu yang menjadi pendukung itu merupakan kubu yang menjadi pendukung dari oposisi atau masyarakat secara luas. Sedangkan kubu yang kontra sudah pasti menola, untuk apa \#2019GantiPresiden, siapa yang mau diganti."(Nur Kholis BEM FISIP UNEJ) 
Meskipun ada berbagai pendapat dan menimbulkan pro dan kontra setiap orang tentunya memiliki hak untuk bebas mengemukakan pendapatnya. Akan tetapi meski memiliki pendapat yang berbedabeda alangkah baiknya apabila menyikapi secara biasa-biasa saja dan tidak perlu sampai menjelek-jelekkan pihak lain.

"Mau yang pro ataupun yang kontra dengan \#2019GantiPresiden, mereka sama-sama mempunyai hak untuk berpendapat karena mereka mempunyai pilihan masing masing. Untuk yang pro ya silahkan gunakan \#2019GantiPresiden, kalau yang kontra ya tidak perlu, bisa gunakan hasthtag-hashtag yang lain. Yang terpenting tidak usah saling mengolok atau menjelekjelekkan."(Ach. Fahmi BEM FISIP $U M J)$

Timbulnya pro dan kontra terhadap adanya \#2019GantiPresiden ini juga menimbulkan dampak-dampak negatif bagi masyarakat. Dampak negatif ini timbul dari adanya ujaran-ujaran kebencian yang terkandung dalam hashtag tersebut sehingga membuat salah satu pihak merasa tidak nyaman hingga memicu terjadinya konflik.
"Dalam sebuah pertarungan pasti ada strategi yang dilakukan dari kedua belah pihak, tapi sekarang ini pro dan kontra seputar \#2019GantiPresiden ini menimbulkan dampak-dampak negatif yang begitu signifikan bahkan hingga menimbulkan pertengkaran antar individu maupun antar ormas yang berujung saling mencaci di sosial media."(Moh. Lutfi BEM FISIP UIJ)

Munculnya \#2019GantiPresiden ini juga di dalangi atau di prakarsai oleh beberapa pihak yang memilihi kepentingan tersendiri terutama dalam hal untuk memenuhi tujuannya yaitu memenangkan salah satu pasangan calon yang terlibat di pemilu presiden 2019 .

"Yang saya dengar dari beberapa media, bahwa adanya \#2019GantiPresiden ini ternyata di dalangi oleh beberapa pihak yang mereka mempunyai tujuan mempunyai kepentingan tertentu yakni untuk memenangkan salah satu paslon." (Ilham W. BEM FISIP UIJ)

Dalam menanggapi \#2019Ganti Presiden sebaiknya tidak terlalu 
berlebihan, boleh menanggapi tapi dengan cara yang baik dan tidak mengikut sertakan emosi di dalamnya. \#2019GantiPresiden ini biarlah menjadi tanggung jawab para penguasa yang memang terlibat dalam kemunculan hashtag ini.

"Tidak perlu ambil pusing dengan hal itu, apalagi sampai ikut berkomentar tentang \#2019GantiPresien, biarkan mereka yang berkuasa saja yang berbicara kita hanya bisa melihat bagaimana hasilnya nanti."(Henry R. BEM $U M S)$

Menjelang masa-masa pemilu pasti akan muncul berbagai isu yang berkaitan dengan pelaksanaan pemilu atau isu yang berkaitan dengan kandidat dalam pemilihan umum. Munculnya sebuah isu tentu akan diikuti dengan munculnya berbagai pendapat dari masyarakat dan bukan tidak mungkin juga akan menimbulkan adanya pro dan kontra. Tapi terjadinya pro dan kontra itu merupakan hal yang biasa dan hal yang wajar mengingat adanya perbedaan pendapat yang dikemukakan oleh masyarakat.

Selain ada opini yang sependapat dengan \#2019GantiPresiden tentunya juga pasti ada opini yang bertentangan dengan pernyataan dalam \#2019GantiPresiden.

"Saya pribadi tidak setuju dengan \#2019GantiPresiden, kenapa harus hashtag itu kenapa tidak hashtag lainnya saja yang lebih bagus. Ganti presiden atau tidak nantinya kan itu tergantung dari kepuasan rakyat dengan pemerintah." (Shinta Y. BEM FISIP UT)

"Saya tidak setuju, karena saya punya pilihan dan penilaian sendiri dan saya tetap pada pilihan saya sendiri, saya juga tidak pernah menanggapi adanya hashtag itu. "(Irma W. BEM FISIP UT)

Jika menyimak dan mengikuti perkembangan mengenai \#2019Ganti Presiden ini tentunya kita akan lebih memahami apa makna sesungguhnya dari \#2019GantiPresiden ini. Namu jika tidak mengikuti perkembangannya, tentu kita akan ketinggalan informasi mengenai hashtag itu bahkan bisa terjadi adanya salah persepsi terhadap \#2019GantiPresiden.

"Saya tidak setuju dengan \#2019GantiPresiden, karena ini ganti 
presiden sedangkan presiden itu kan suatu lembaga berarti yang diganti itu lembaganya. Memang kalau diganti mau diganti dengan apa? Kerajaan? Kan tidak mungkin hal seperti itu terjadi."(Henry R. BEM $U M S)$

\#2019GantiPresiden dikemukakan oleh rakyat, menandakan bahwa rakyat merasa tidak puas dengan pemerintahan saat ini dan menginginkan adanya pergantian presiden. Yang dimaksud presiden dalam hashtag ini adalah seorang pemimpin bangsa bukanlah sebuah lembaga. Dalam menyikapi sebuah fenomena sebaiknya kita harus memahaminya terlebih dahulu.

Opini tersembunyi juga turut mewarnai adanya \#2019GantiPresiden. Opini ini muncul karena pendapat yang mereka miliki bertentangan dengan \#2019GantiPresiden dan mereka enggan untuk mengemukakan pendapatnya karena pendapat mereka berbeda dengan pendapat kebanyakan orang dan membuat mereka jadi merasa perlu untuk tidak menyampaikan pendapatnya secara terang-terangan.

"Menurut saya setuju atau tidak itu jawaban personal, karena kalau cuma \#2019GantiPresiden saja itu belum tentu sesuai dengan kenyataan yang ada di lapangan nanti."(Lailatul A. BEM FISIP UNEJ)

"Ini pertanyaan yang sangat pribadi menurut saya. Tapi kalau dengan hashtagnya saya setuju-setuju saja karena hashtag itu merupakan hak dari masing-masing masyarakat untuk mengungkapkan pendapatnya. "(Ilham W. BEM FISIP UIJ)

Sebuah hashtag tidak dapat menentukan apakah seseorang akan setuju atau tidak dengan hashtag itu. Karena setiap orang sudah menentukan pilihannya masing-masing dan mereka juga berhak untuk menentukan keputusannya sendiri.

"Saya sendiri masih tidak tahu mau setuju atau tidak dengan \#2019GantiPresiden ini karena saya masih di kubu abu-abu belum menentukan akan memilih siapa nantinya. Bahkan saat ini saya berencana untuk golput karena saya sudah bisa menentukan pilihan sendiri. Kalau memang yang ada ini tidak cocok dengan saya ya saya 
tidak akan memilih memiliki kemampuan untuk siapapun."(Rifaldo A. BEM FISIP mempengaruhi pilihan politik seseorang $U M J)$ secara langsung maupun tidak langsung.

Sebagai warga negara yang baik, seluruh rakyat Indonesia masing-masing sudah memiliki hak pilihnya. Hendaknya hak pilih tersebut digunakan sebaikbaiknya demi kemajuan bangsa Indonesia kedepannya. Satu suara sangat berarti untuk perubahan bangsa yang lebih baik.

Berdasarkan jawaban yang diperoleh dari para informan dapat diketahui bahwa terdapat pendapat mayoritas dan minoritas terhadap \#2019GantiPresiden. Pendapat mayoritas merupakan pendapat yang sangat mendukung adanya \#2019GantiPresiden karena berbagai alasan, orang-orang yang memiliki pendapat mayoritas ini akan secara terbuka menyampaikan pendapatnya kepada khalayak. Sedangkan pendapat minoritas merupakan pendapat yang tidak sesuai dengan adanya \#2019GantiPresiden ini, namun mereka tidak akan secara terbuka menyampaikan pendapatnya bahkan cenderung memilih diam. Mampukah \#2019GantiPresiden mempengaruhi pilihan politik seseorang

Adanya \#2019GantiPresiden ini membawa pengaruh yang cukup signifikan bagi masyarakat. Hashtag ini
"Lumayan berpengaruh, karena adanya \#2019GantiPresiden itu jadi banyak orang yang ikut-ikut. Yang awalnya hanya sekedar ikut-ikut kemudian menjadi setuju dengan hashtag itu akhirnya bisa jadi mendukung dan ikut menggunakan \#2019GantiPresiden." (Ach. Fahmi BEM FISIP UMJ)

"Bisa saja mempengaruhi orang lain, karena \#2019GantiPresiden ini booming pasti orang awam yang melihat banyaknya orang yang membahas \#2019GantiPresiden ini mereka juga bisa terpengaruh."(Shinta Y. BEM FISIP $U T)$

Pengaruh dari adanya \#2019GantiPresiden ini sangat kuat terutama dengan kemunculannya di sosial media. Karena kemudahan dalam mengakses media sosial maka pengguna media sosial juga terpengaruh dengan adanya hashtag ini. 
“\#2019GantiPresiden ini sangat bisa memperngaruhi orang lain. Saat ini kita hidup di zaman yang dimana media sosial itu benar-benar berperan, semua informasi bisa diperoleh di media sosial dengan mudah. Apalagi saat ini siapa yang tidak menggunakan media sosial."(Lailatul A. BEM FISIP UNEJ)

Meskipun tidak semua orang terpengaruh dengan \#2019GantiPresiden, viralnya \#2019GantiPresiden membuat masyarakat menjadi lebih mengenal siapa sosok yang dimaksud dalam viralnya hashtag ini.

"Dengan viralnya
\#2019GantiPresiden ini bisa
membuat masyarakat jadi lebih
mengenal sosok dari paslon yang
dimaksud. Karena di mindset saya
sendiri kalau sudah membahas
\#2019GantiPresiden langsung
teringat pada sosok yang dimaksud
itu."(Ilham W. BEM FISIP UIJ)

Orang yang memiliki pemikiran yang lebih luas tentu tidak akan mudah terepngaruh dengan adanya \#2019GantiPresiden ini, mereka pasti akan melihat dan menilai terlebih dahulu apakah kandidat ini merupakan pemimpin yang baik bagi bangsa Indonesia.

"Bagi masyarakat yang sudah terpelajar apalagi tahu tentang politik tentu dia tidak mudah terpengaruh dengan hanya sebuah hashtag. Sebagai masyarakat yg terpelajar pasti akan mengedepankan pilihan yang rasional bukan pilihan emosional."(Nur Kholis BEM FISIP UNEJ)

"Kalau orang awam yang tidak mengerti politik itu pasti bisa terpengaruh. Sedangkan orang yang mengerti tentang politik pasti mereka akan melihat dulu asalusulnya."(Irma W. BEM FISIP UT)

“\#2019GantiPresiden ini belum tentu bisa mempengaruhi pilihan politik orang lain karena setiap orang pasti memiliki pilihan sendiri dan bisa menilai mana yang baik dana mana yang buruk."(Faisol A. BEM UMS)

"Saat ini kita, masyarakat Indonesia ini sebenarnya mudah terpengaruh apalagi dengan penggunaan media sosial karena saat ini pun media bisa 
mempengaruhi orang lain."(Nur Kholis BEM FISIP UNEJ)

Selain mudah untuk terpengaruh, rakyat Indonesia juga banyak yang menentukan pilihannya tidak berdasarkan hati nurani melainkan asal pilih saja tanpa melihat asal-usul dan jejak karirnya di dunia politik.

\section{“\#2019GantiPresiden memang} mampu mempengaruhi orang lain, apalagi saat ini banyak orang yang memilih tapi tidak berdasarkan hati nurani, tidak melihat jejak karirnya, mereka hanya asal pilih saja. Karena mudahnya terpengaruh bisa saja hari ini mereka pilih paslon nomor 1 dan pada saat pemilu berubah pemikiran hanya karena omongan orang. "(Rifaldo A. BEM FISIP UMJ)

\#2019GantiPresiden ini mampu memberi pengaruh yang besar bagi masyarakat. Diawal kemunculannya saja sudah menuai kontroversi dan sangat menarik perhatian masyarakat, bagi orang yang awam yang tidak terlalu memahami dunia politik tentu akan sangat mudah terpengaruh. Viralnya hashtag ini di media juga mampu untuk mempengaruhi seseorang apalagi media juga menyertakan data-data, isu, bahkan kelemahan dari paslon yang tentunya sangat berpengaruh untuk merubah persepsi orang lain. Selain itu pada dasarnya masyarakat memang mudah terpengaruh oleh isu apapun yang sedang beredar dan juga mudah berubah pikiran hanya karena omongan dari orang lain.

Sedangkan bagi masyarakat yang cukup memahami dunia politik pasti tidak akan mudah terpengaruh karena dia akan melihat dan menilai seperti apa kandidat yang ada melalui asal-usul serta jejak karirnya. Selain itu orang yang tahu tentang politik pasti akan mengedepankan pilihan rasional bukan pilihan emosional semata.

\section{Kesimpulan}

Dari data-data yang telah diperoleh dari 10 orang informan diketahui bahwa mereka semua mengetahui informasi mengenai \#2019GantiPresiden. Dalam memperoleh suatu informasi dari 10 orang informan tersebut lebih banyak menggunakan media massa (cetak dan elektronik) dan media sosial sebagai sumber informasi, dari data yang ada terdapat 8 orang informan menggunakan media sosial seperti facebook, twitter, dan instagram sebagai sumber informasinya karena aksesnya yang sangat mudah dan dan informasi yang ada di media sosial 
lebih ter-update dibanding media yang lain.. Sedangkan 2 orang lainnya memilih menggunakan situs berbagi video yakni youtube untuk memperoleh suatu informasi, mereka beralasan bahwa informasi yang diperoleh melalui youtube dapat dilakukan pemutaran secara berulang-ulang sehingga mereka tetap bisa menyaksikannya kembali.

Pendapat para informan mengenai \#2019GantiPresiden juga beraneka ragam. Dari 10 orang informan memiliki pendapat yang berbeda-beda, dari data yang ada diketahui bahwa terdapat sebanyak 4 orang memberikan respon yang biasa saja, mereka menyatakan bahwa adanya \#2019GantiPresiden ini merupakan suatu hal yang biasa mengingat bahwa di tahun 2019 ini merupakan tahun politik dan memang musimnya untuk melakukan proses kampanye. Namun ada satu informan yang menganggap bahwa adanya
\#2019GantiPresiden dan juga hashtaghastag yang lainnya ini termasuk makar. Istilah makar sering diidentikkan dengan istilah kudeta yang berarti tindakan pemberontakan untuk menggulingkan kekuasaan yang sah. 3 orang informan lainnya berpendapat bahwa \#2019GantiPresiden ini merupakan suatu hal yang bagus karena mampu menarik perhatian audien bahkan menilbulkan kontroversi di masyarakat, mereka juga mengatakan bahwa hashtag ini merupakan suatu strategi baru dalam konteks politik. Seorang informan lainnya mengatakan bahwa adanya \#2019GantiPresiden ini merupakan upayan untuk memprovokasi rakyat dan membuat suasana jadi semakin panas. Dan seorang informan lainnya berpendapat bahwa hashtag ini merupakan suatu hal yang aneh karena yang bisa menentukan pergantian presiden itu hanyalah rakyat karena semua pilihan itu ada di tangan rakya 


\section{Daftar Pustaka}

Effendy, Onong Ucjhana.1984. Ilmu

Komunikasi Teori dan Praktek.

Bandung:PT Remaja Rosdakarya. ,2004. Dinamika

Komunikasi. Bandung: PT Remaja Rosdakarya.

McQuail, Denis. 1991.Teori Komunikasi Massa. Jakarta:Erlangga.

Morissan.2013.Teori Komunikasi Individu

Hingga Massa. Jakarta:Kencana Prenamedia Group.

Mulyana, Deddy. 2014. Komunikasi

Politik Politik Komunikasi.

Bandung:PT Remaja Rosdakarya

Nurudin. 2007.Pengantar Komunikasi

Massa. Jakarta:PT Raja Grafindo

Persada.
. 2008.Komunikasi Propaganda.

Bandung:PT Remaja Rosdakarya.

Pawito.2015.Komunikasi Politik Media

Massa dan Kampanye Pemilihan.

Yogyakarta:Jalasutra.

Rakhmat, Jalaluddin.2009. Metode Penelitian Komunikasi.

Bandung:PT Remaja Rosdakarya.

Usman, Husaini.2009. Metodologi Penelitian Sosial. Jakarta:PT Bumi Aksara.

\section{Referensi lainnya :}

http://www.dictio.id/

http://www.komunikasi95.blogspot.com

https://id.wikipedia.org/wiki/2019GantiPr esiden 